\title{
Morphometric Study of Normal Human fetal Submandibular Salivary Gland
}

\author{
Dr. Yogini K Karnewar ${ }^{1}$, Dr. A A Holkunde ${ }^{2}$, Dr. V B Bhagwat ${ }^{3}$, \\ Dr. D S Joshi ${ }^{4}$, Dr. S S Dhapate ${ }^{5}$ \\ I \& 2 (MD Anatomy, SRTR GMC, Ambajogai, Dist Beed, Maharashtra, India) \\ ${ }^{3}$ (Asst. Professor, Department of Anatomy, SRTR GMC Ambajogai, Dist. Beed, Maharashtra, India) \\ ${ }^{4}$ (Prof.\& Head, Department of Anatomy, Dr. S. C. Govt. Medical College, Nanded, Maharashtra, India) \\ ${ }^{5}$ (Prof.\& Head, Department of Anatomy, SRTR GMC Ambajogai, Dist. Beed, Maharashtra, India)
}

\begin{abstract}
Morphometric study of submandibular salivary gland in 30 normal human fetuses at different stages of development was done. Morphometric parameters studied in fetal submandibular glands were length and breadth of glands. It was observed that with increase in gestational age of fetuses, there was gradual increase in morphometric parameters of fetal submandibular salivary glands of both sides.
\end{abstract}

Keywords: fetuses, histogenesis, human, morphometry, submandibular salivary gland.

\section{Introduction}

Salivary gland is any cell or organ discharging secretion into the oral cavity. Distinction is made primarily between major salivary glands and minor salivary glands[1]. Various studies have been done on this gland in human fetuses and adults. Gibson (1983) studied the submandibular gland of six human fetuses using light and electron microscopes and observed lumen in the acini and ducts at the age of 13.5 to 16 weeks[2]. The time of formation and number of acini, ducts and the functional maturity of the gland were studied by ElMohandes et al (1987) in human fetuses ranging from 10 weeks to full term[3]. In a study by Martinez et al (1991) in 8 fetuses, the submandibular gland was found to appear before the parotid gland [4].The morphogenetic events in submandibular gland were studied in 37 human fetuses and the gland was found to grow from the medial paralingual groove (Merida-Velasco et al, 1993)[5]. The location of orifice of human submandibular gland was observed to be in the medial paralingual sulcus. Apart from the above cited studies, many experiments were done on hamster and mice (Chaudry et al, 1986[6]; Watanabe et al, 1997[7]). Culter and Mooradian (1987) found canalisation and lumen formation at 17th day of gestation in rat submandibular gland[8].Sivakumar $\mathrm{M}$ et al in 2003 had done histogenesis and morphometric study of human fetal submandibular glands[9].

Though various studies have been undertaken to study microscopic studies on human fetal submandibular gland but morphometric studies are still going on. There is lot to be done in morphometric studies. So the present study is undertaken to highlight some important points in morphometry of normal human fetal submandibular glands.

\section{Material \& methods}

30 normal human fetuses ranging from 12 weeks to 38 weeks of gestational age were chosen for the study. Age was assessed using crown-rump length (CRL) and correlated with available history. They were fixed in $10 \%$ formalin and after a week's time submandibular glands were dissected, their relations and duct patterns were noted and then they were removed. Their dimensions like length and breadth were measured and tabulated. 

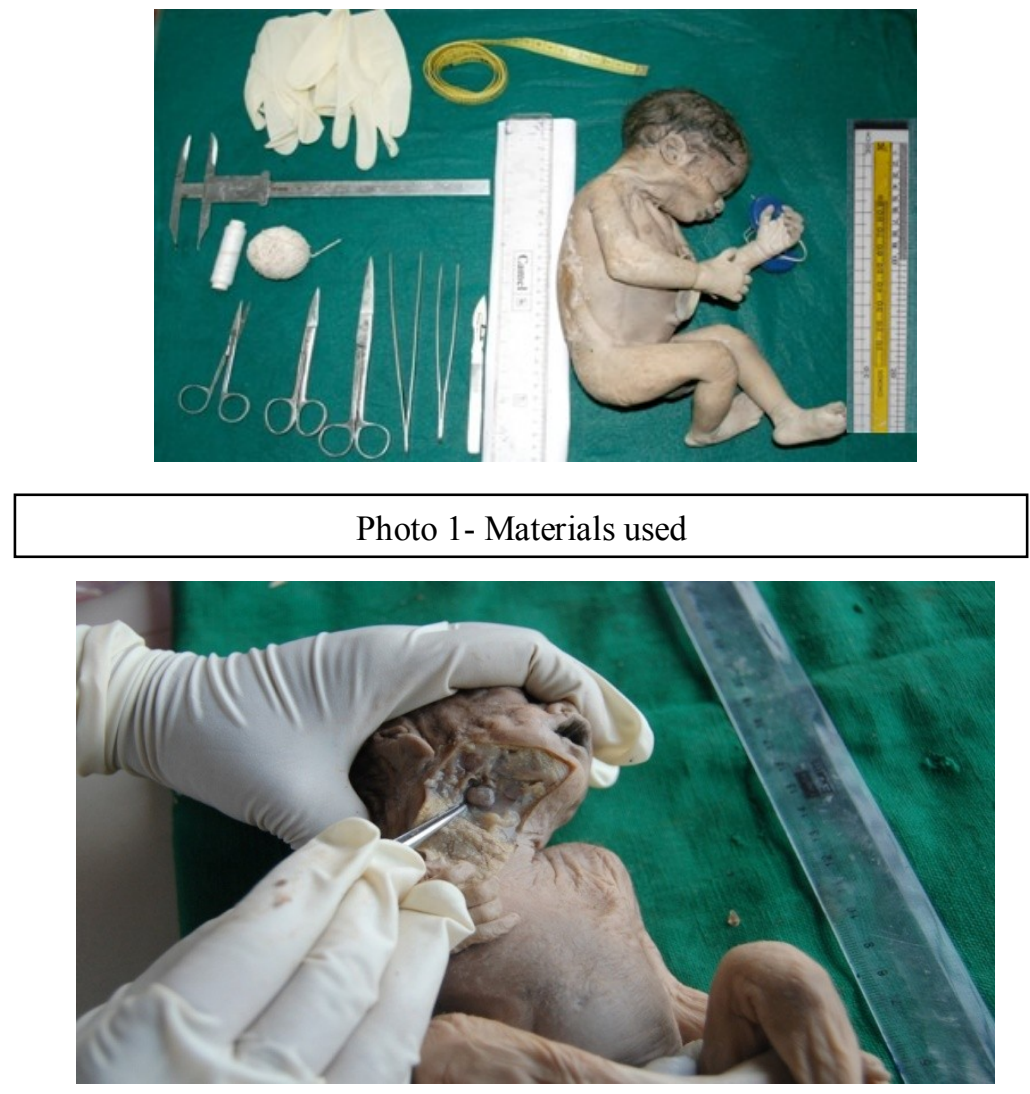

Photo 2- Submandibular Salivarv Gland in situ

The fetuses ranging from 10 weeks of gestation to full term were divided into 3 groups viz., Group I [10-16 weeks], Group II [18-26 weeks], and Group III [28 weeks - full term].

Group I [10 - 16 weeks]

\section{Observations}

The morphometric study of the submandibular gland showed that on average it measured $8.40 \mathrm{~mm}$ in length and $5.71 \mathrm{~mm}$ in breadth [Table - I].

Table I: Dimensions Of Human Fetal Submandibular Salivary Glands

\begin{tabular}{|l|l|l|}
\hline \multicolumn{2}{|l|}{ Length $(\mathrm{mm})$} & Breadth $(\mathrm{mm})$ \\
\hline Group I (12-16 weeks) & 8.50 & 5.76 \\
\hline Rt & 8.30 & 5.66 \\
\hline Lt & 8.40 & 5.71 \\
\hline Average & 14.50 & 8.54 \\
\hline Group II (18-26 weeks) & 14.16 & 8.32 \\
\hline Rt & 14.33 & 8.43 \\
\hline Lt & \multicolumn{2}{|l|}{} \\
\hline Average & 17.33 & 11.80 \\
\hline Group III (28-38 weeks) & 16.90 & 10.72 \\
\hline Rt & 17.11 & 11.26 \\
\hline Lt & \\
\hline Average
\end{tabular}

Group II [18 - 26 weeks]:

The gland was $14.33 \mathrm{~mm}$ in length and $8.43 \mathrm{~mm}$ in breadth. When compared to Group I, the dimensions of the gland increased 1.7 times (Table - I).

Group III [28week - 38 weeks]:

The gland measured $17.11 \mathrm{~mm}$ in length, $11.26 \mathrm{~mm}$ in breadth. The dimensions increased 2 time than that of Group I (Table - I). 


\section{Discussion}

The gland length and breadth were measured in $\mathrm{mm}$.

1.Length of Submandibular gland-

The findings of present study are tabulated in table II for comparison with gland length findings of the previous worker Sivakumar M et al [9].

\begin{tabular}{|l|l|l|l|l|}
\hline \multirow{2}{*}{$\begin{array}{l}\text { Fetal } \\
\text { Groups }\end{array}$} & \multicolumn{2}{|l|}{ Gland Length $(\mathrm{mm})$} & \multicolumn{2}{|l|}{} \\
\cline { 2 - 5 } & Sivakumar M & Right & Present Study & Right \\
\cline { 2 - 5 } & Left & 9 & 8.3 & 8.5 \\
\hline $12-16$ wks & 8.8 & 15 & 14.16 & 14.50 \\
\hline $18-26$ wks & 14.8 & 17 & 16.90 & 17.33 \\
\hline $28-38$ wks & 16.5 & & Left & \\
\hline
\end{tabular}

In study of Sivakumar M et al [9], first group included fetuses from 10-12 weeks.

2.Breadth of Submandibular gland

The findings of present study are tabulated in table III for comparison with gland breadth findings of the previous worker Sivakumar M et al [9].

\begin{tabular}{|l|l|l|l|l|}
\hline \multirow{2}{*}{$\begin{array}{l}\text { Fetal } \\
\text { Groups }\end{array}$} & \multicolumn{4}{|l|}{ Gland Breadth (mm) } \\
\cline { 2 - 5 } & Sivakumar M & Right & Present Study \\
\cline { 2 - 5 } & Left & 5.8 & Left & Right \\
\hline $12-16$ wks & 5.5 & 9 & 8.66 & 5.76 \\
\hline $18-26$ wks & 9 & 12 & 10.72 & 8.54 \\
\hline $28-38$ wks & 11 & 11.80 \\
\hline
\end{tabular}

In study of Sivakumar M et al [9], first group included fetuses from 10-12 weeks.

From tables II \& III, It was seen that values of gland length and breadth given by Sivakumar M et al [9] were more or less similar to the findings of the present study.

\section{Conclusion}

It was observed that length and breadth of human fetal submandibular gland increased as

-Gestational age of fetus increases.

-Birth weight of fetus increases.

-Crown rump length of fetus increases.

Submandibular gland tumours are one of the most complex and relatively rare group of lesions encountered in oral pathology practice. Their complexity is attributed to heterogeneity of the cells of origin of these lesions. Despite this, the knowledge of histogenesis and morhogenetic concepts of salivary gland tumorigenesis greatly helps the pathologist in classifying these lesions as well as determining the prognosis [10].

\section{References}

[1] Gray H, Gray's anatomy, the anatomical basis of medicine and surgery (Churchill Livingstone,2000).

[2] Gibson, M.H, The prenatal human submandibular gland: a histological, histo-chemical and ultrastructural study. Anatomischer Anzeiger, 153(1), 1983, 91-105.

[3] El - Mohandes, E.A; Botros, K.G; Bondok A.A,Prenatal development of the human submandibular gland. Acta Anatomica. 130(3), 1987, 213-218.

[4] Martinez, G; Caltabiano, C; Leonardi, R; Canterella, M.I. ,Histo-ontogenetic study of the major salivary glands and Chievitz's organ. Stomatologia Mediterrania. 11(1), 1991,33-37.

[5] Merida - Velasco, J.A. ; Sanchez - Montesinos, I; Espin - Ferra, J; Garcia - Garcia, J.D; Garcia-Gomez, S; Roldan- Schilling, V, Development of the human submandibular salivary gland. Journal of Dental Research 72(8),1993, 1227-1232.

[6] Chaudry, A.P; Cutler, L.S; Schmutz, J.A; Yamane, G.M; Pierri, L.K; Sunderraj, M, Development of the hamster submandibular gland. II. The ductal system. Journal of submicroscopic cytology. 18(3),1986, 529-536.

[7] Watanabe, I; Jin, C; Nagata, T, Field emission SEM, conventional TEM and HVTEM study of submandibular gland in prenatal and postnatal aging mouse. Histology and Histopathology. 12(2),1997, 447-457.

[8] Cutler, LS; Mooradian, B.A, Lumen formation during development of the rat Submandibular gland. Journal of Dental Research. 66(10), 1987, 1559-1562.

[9] Sivakumar M, Sud M, Vathsala V, Histogenesis and morphometric study of human foetal submandibular salivary gland. J Anat Soc India, 52(1),2003, 3-6.

[10] Dwivedi N, Agarwal A, Raj V, Chandra S, Histogenesis of salivary gland neoplasms, Indian J Cancer.50(4),2013,361-6. 